\title{
The Effect of Low-Temperature Spray Drying with Dehumidified Air on Phenolic Compounds, Antioxidant Activity, and Aroma Compounds of Rapeseed Honey Powders
}

\author{
Katarzyna Samborska ${ }^{1}$ (D) Aleksandra Jedlińska ${ }^{1} \cdot$ Artur Wiktor $^{1} \cdot$ Dorota Derewiaka $^{1} \cdot$ Rafał Wołosiak $^{1}$. \\ Arkadiusz Matwijczuk $^{2}$ - Wojciech Jamróz ${ }^{3} \cdot$ Krystyna Skwarczyńska-Maj $^{3} \cdot$ Dariusz Kiełczewski $^{3} \cdot$ Łukasz Błażowski $^{3}$. \\ Marcin Tułodziecki ${ }^{3} \cdot$ Dorota Witrowa-Rajchert $^{1}$
}

Received: 5 December 2018 / Accepted: 28 February 2019 / Published online: 30 March 2019

(C) The Author(s) 2019

\begin{abstract}
The influence of low-temperature spray drying (inlet/outlet air, $75 / 50{ }^{\circ} \mathrm{C}$ ) with the use of dehumidified air on rapeseed honey phenolics, antioxidant activity, and aroma compounds was investigated. Maltodextrin and NUTRIOSE® were used as carriers. Additionally, skimmed milk was tested as water substitute for feed solution preparation. Honey powders obtained by this method were characterized by high antioxidant activity and rich aroma. Changes in aroma profile during drying at low temperature were recognized as favorable and creating desirable fragrance of the product. In the case of $80 \%$ honey powders ( $20 \%$ of carrier), the investigated properties were not deteriorated comparing to pure honey before drying. Thus, this level of carrier addition can be treated as optimal from the point of view of bioactive properties retention during low-temperature spray drying. Such low carrier addition was not presented before in case of honey spray drying, and is favorable due to the perception of such product as natural. If used as food component, the dose of such honey-rich powder can be reduced comparing to traditional products containing higher amount of carrier (usually not lower than $50 \%$ ).
\end{abstract}

Keywords Honey $\cdot$ Spray drying $\cdot$ Phenolic compounds $\cdot$ Antioxidant activity $\cdot$ Volatile compounds

\section{Introduction}

Honey is a rich natural source of compounds important in nutrition, i.e., phenolics, antioxidants, flavonoids, organic acids, carotenoid-derived compounds, nitric oxide metabolites, amino acids, and proteins (Vallianou et al. 2014; Suhag et al. 2016). Honey phenolic compounds act as natural antioxidants and are increasingly popular, thanks to their role in contributing to human health (Pérez-Pérez et al. 2013, Dong

Katarzyna Samborska

katarzyna_samborska@sggw.pl

1 Faculty of Food Sciences, Warsaw University of Life Sciences WULS-SGGW, Nowoursynowska 159c, 02-776 Warsaw, Poland

2 Department of Physics, Faculty of Production Engineering, University of Life Sciences in Lublin, Akademicka 13, 20-950 Lublin, Poland

3 MASPEX-GMW Sp. z o.o. Sp. k, Wadowice, Poland et al. 2011). Honey composition, and therefore phenolic content, varies due to differences in plant types, climate, and environmental conditions (Kücük et al. 2007). TapiaCampos et al. (2017) reported TPC in Mexican multifloral honey in a range from 62.13 to $136.84 \mathrm{mg} \mathrm{GA} 100 \mathrm{~g}^{-1}$. In rapeseed honey, it varied from $34.33 \pm 0.89$ (GarcíaTenesaca et al. 2018) to $240 \mathrm{mg} \mathrm{GA} 100 \mathrm{~g}^{-1}$, with most samples in a range of 70-90 mg GA $100 \mathrm{~g}^{-1}$ (Lachman et al. 2010; Bobiş et al. 2011; Kuś et al. 2014). Antioxidant activity is another important honey quality indicator. Antioxidants are substances that protect the body cells from damage caused by unstable free radicals (Bundit et al. 2016). In honey, the antioxidant activity is related to the presence of vitamin $\mathrm{C}$, flavonoids (such as apigenin, pinocembrin, kaempferol, quercetin, galangin, chrysin, and hesperetin), phenolic acids (such as ellagic, caffeic, $p$-coumaric, and ferulic acids), enzymes (such as catalase, peroxidases, superoxide dismutase, glucose oxidase), and peptides, tocopherols, and Maillard reaction products (Vallianou et al. 2014; Khalil et al. 2010). 
Honey is consumed also due to its unique taste and aroma. Moreover, aromatic substances also contribute to antibacterial properties of honey. Bogdanov (1997) fractionated 10 different honeys into four basic substance groups: volatile; nonvolatile and nonpolar; acidic; and basic substances. On average, volatiles were responsible for $11 \%$ of antibacterial activity. Several authors identified different numbers of honey volatile compounds: 113 in orange, eucalyptus, and chestnut honeys (Verzera et al. (2001), 38 in citrus, 32 in rosemary, 29 in multifloral honey (Escriche et al. 2009). Volatile compounds may provide information about the botanical origin of honey, as some of them are present in the majority of honeys (the mutual proportions of these substances can be different), while other are unique to particular types of honey (Escriche et al. 2009; Wolski et al. 2006). The chemical families into which the volatile compounds in honey belong include hydrocarbons, aldehydes, alcohols, ketones, acids, esters, benzene and its derivatives, furan and pyran, norisoprenoids, terpenes and its derivatives, sulfur components, and cyclic compounds (Manyi-Loh et al. 2011). The major constituents dominating the headspace of Polish willow honey were monoterpenes (Jerković et al. 2014). Many authors agree that certain volatile compounds such as furan derivatives (i.e., furfural, methylfurfural, and furfuryl alcohol) are good indicators of heat treatment and storage conditions (Escriche et al. 2009). Wootton et al. (1978) presented that high-point compounds of honeys were decomposed during storage or processing at $50{ }^{\circ} \mathrm{C}$, while other components, such as furfural, furanaldialdehyde, 2-acetylfuran, and aceton, increased in level.

Powdered honey is an attractive substitution for natural liquid honey, highly demanded by food and pharmaceutical industries. Although during the last decade, several papers dealing with honey drying were published; the issue of honey powder's biological value, as affected by drying process, was not enough investigated. Among drying methods, spray drying is the most favorable for honey dehydration (Suhag and Nanda 2016b). It leads to the production of free-flowing powder during one fast operation. Moreover, spray drying process has been used for decades to encapsulate food ingredients such as flavors, lipids, and carotenoids (Mahdavi et al. 2014). The study presented by Waterhouse et al. (2017) demonstrated the feasibility of producing spray-dried powders rich in dietary fiber and antioxidants (including anthocyanins) with short processing time and low investment capital. Due to fast evaporation of water, the entrapment of the interest compound occurs quasi-instantaneously (Gharsallaoui et al. 2007). Thus, honey dehydration by spray drying with the use of selected wall materials can be treated as a microencapsulation of this valuable natural product containing sensitive or volatile additives. This process is a source of totally new ingredient with matchless properties. However, it has to be emphasized that honey powder produced by traditional high-temperature spray drying has to contain usually at least $50 \%$ of carrier material (Samborska et al. 2015). As was presented recently, the reduction of drying temperature, possible as a result of inlet air dehumidification, made it, in turn, possible to reduce the amount of carrier in honey powder (Jedlińska et al. 2019). The physical properties of such honey powders containing only $20 \%$ of carrier material were investigated and it was concluded that these powders were characterized by acceptable flowability and hygroscopicity.

As was mentioned above, the biological properties of honey powder were not enough investigated. Some focus was done on the influence of spray drying on enzymatic activity, giving the conclusion that enzymes are not considerably degraded during such drying. As was presented by Samborska and Czelejewska (2014) and Samborska et al. (2017), honey diastase activity after spray drying stayed at the same level or was only slightly deteriorated. Polyphenols and other antioxidants usually are easily to degrade during thermal treatment, including drying. Suhag and Nanda (2015) optimized spray drying conditions to develop nutritionally rich honey powder using whey protein concentrate (WPC), aonla (Emblica officinalis Gaertn.), and basil (Ocimum sanctum) extract. Increasing inlet temperature (from 160 to $180^{\circ} \mathrm{C}$ ) lowered antioxidant activity and total phenolic and vitamin $\mathrm{C}$ content. On the contrary, there are also some examples of increased phenolic content determined after thermal treatment (cooking, steaming, pasteurization). This may result from phenolic isomerization, hydrolysis (resulting in decomposition of complex compounds of sugar moiety cleavage), or deglycosylation by thermohydrolysis in lower water activity conditions (roasting). Such phenomena might also depend upon certain phenolic composition, as some were found to exhibit protective effects on other compounds. Higher levels of phenolics after processing were more often reported for phenolic acids than more complex compounds, e.g., flavonoids; therefore, a significant presence of phenolic acids may be one of the factors as well (Amarowicz et al. 2009; van Boekel et al. 2010; Ioannou and Ghoul 2012; Tiwari and Cummins 2013).

Nevertheless, any method which would make possible to reduce the temperature of honey processing, is very desirable. Thus, spray drying with the use of dehumidified air is an interesting option for honey dehydration, and potentially could lead to obtain powdered product of not degraded biological activity. The aim of work was to investigate the effect of low-temperature spray drying with the use of dehumidified air on phenolic compounds, antioxidant activity, and aromatic substances of rapeseed honey. Two types of carrier materials were tested. Additionally, the produced powders were characterized by FTIR spectroscopy. The research method is currently gaining popularity in the context of analyzing food products with respect to their potential health benefits, e.g., honeys, oils, and juices. 


\section{Materials and Methods}

\section{Materials}

Rapeseed honey $(\mathrm{H})$ was derived from a local apiarist (Pasieka Warmińska, Gietrzwałd, Poland). Maltodextrin MALTOSWEET180 (M), characterized by DE 17.0-19.9, from TateandLyle (Slovakia), and NUTRIOSE FM06 (N) from Roquette (France) were used as carrier materials. Skimmed milk (m) from Mlekovita (Poland) was used as water substitution for feed solution preparation in one variant.

\section{Feed Solutions Preparation}

Six variants of honey/carrier solutions were prepared by mechanical mixing with water or skimmed milk (Table 1). Honey to carrier solids ratio was changed from $60: 40$ to $70: 30$ and 80:20 in order to produce honey powder of substantially increased honey content. NUTRIOSE was tested as a carrier providing beneficial prebiotic properties, so that to propose honey powder of added value. In each variant, feed solution concentration was $60 \%$. It was selected in preliminary experiments, after the observation that the processing of dehumidified air spray drying (DASD) is much different than traditional SD, and high feed solution concentration is preferred (Jedlińska et al. 2019). Five hundred grams of each feed solution was spray-dried in duplicate.

\section{Spray Drying}

NIRO MINOR laboratory spray drier (GEA, Denmark) equipped with an external air dehumidification system, composed of cooling unit TAEevo TECH020 (MTA, Italy), and condensation-adsorption unit ML270 (MUNTERS, Sweden), was applied. During experiments, the humidity of air entering spray drier was not higher than $0.5 \mathrm{~g} \mathrm{~m}^{-3}$. Due to different processing of drying with the use of dehumidified air comparing to typical conditions spray drying, drying parameters were adjusted during preliminary experiments, and were as follows: feed rate $0.22 \mathrm{~mL} \mathrm{~s}^{-1}$, rotary speed of atomizing disc 26,000 rpm (compressed air pressure 4.5 bar), inlet/outlet air temperature $75{ }^{\circ} \mathrm{C} / 50{ }^{\circ} \mathrm{C}$. Spray drying procedure was performed in duplicate for each experimental variant.

\section{Honey and Powder Properties}

\section{Water Content}

Water content (WC) in honey was measured by refractometry, while in powders it was determined by oven method: approximately $1 \mathrm{~g}$ of powder was dried at $105{ }^{\circ} \mathrm{C}$ during $4 \mathrm{~h}$.

\section{Total Phenolic Content}

Extraction Procedure Samples of honeys or powders (5 g) were reconstituted in $10 \mathrm{~mL}$ of water and made up to $50 \mathrm{~mL}$ with ethanol (Avantor Performance Materials). Mixtures were shaken for $30 \mathrm{~min}$ at ambient temperature, then stored for $24 \mathrm{~h}$ at $4{ }^{\circ} \mathrm{C}$ and filtered. Carriers (2 g) were reconstituted with $50 \mathrm{~mL}$ of water following the same procedure. So-prepared extracts were used for total phenolic content (TPC) determination, DPPH test, and CUPRAC test, according to the procedures described below.

TPC was determined with the Folin-Ciocalteu reagent in alkaline environment. Extracts were mixed with $20 \% \mathrm{Na}_{2} \mathrm{CO}_{3}$ solution (Avantor Performance Materials), water, and FolinCiocalteu reagent (Avantor Performance Materials) according to the method of Singleton and Rossi (1965). Absorption at $700 \mathrm{~nm}$ was measured spectrophotometrically (UV-mini 1240 spectrophotometer, Shimadzu, Japan). TPC was expressed as gallic acid (Sigma-Aldrich) equivalents (based on previously prepared standard curve) per $100 \mathrm{~g}$ of honey solids, and per $100 \mathrm{~g}$ of powder solids (in case of powders, results were corrected for respective carrier blank).

\section{Antiradical Activity (DPPH Test)}

The scavenging activity against 2,2-diphenyl-1picrylhydrazyl radical (DPPH, Sigma-Aldrich) was evaluated according to the modified method of Brand-Williams et al. (1995). One milliliter of extract (4 $\mathrm{ml}$ in case of carriers) was diluted to $4 \mathrm{ml}$ with methanol and mixed with $1 \mathrm{~mL}$ of DPPH solution $\left(0.5 \mathrm{~mol} \mathrm{~L}^{-1}\right)$. After $30 \mathrm{~min}$ of incubation at

Table 1 Variants of honey/carrier feed solutions spray-dried with the use of dehumidified air

\begin{tabular}{lllll}
\hline Variant & Carrier & Honey solids (\%) & Carrier solids (\%) & Solvent \\
\hline H60M & Maltodextrin & 60 & 40 & Water \\
H70M & Maltodextrin & 70 & 30 & Water \\
H80M & Maltodextrin & 80 & 20 & Water \\
H80N & NUTRIOSE & 80 & 20 & Water \\
H80MN & Maltodextrin and NUTRIOSE in 1:1 ratio & 80 & 20 & Water \\
H80MNm & Maltodextrin and NUTRIOSE in 1:1 ratio & 80 & 20 & Skimmed milk \\
\hline
\end{tabular}


room temperature, the absorbance was measured at $517 \mathrm{~nm}$ (UV-mini 1240 spectrophotometer, Shimadzu, Japan). The calibration curve was prepared with Trolox (Sigma-Aldrich) dilutions in appropriate solvent. Results were expressed as milligram of Trolox equivalents per $100 \mathrm{~g}$ of honey solids, and per $100 \mathrm{~g}$ of powder solids. Additionally, the contribution of carrier in DPPH antioxidant activity of investigated powders (\%) was calculated.

\section{Cupric lon Reducing Antioxidant Capacity (CUPRAC Test, Apak et al. 2008)}

The reducing activity of extracted antioxidants based on the reduction of $\mathrm{Cu}(\mathrm{II})$ to $\mathrm{Cu}(\mathrm{I})$ was measured by mixing $1 \mathrm{~mL}$ of $\mathrm{CuCl}_{2}$ solution (Sigma-Aldrich, $10 \mathrm{mmol} \mathrm{L}^{-1}$ ), $1 \mathrm{~mL}$ of neocuproine solution (Sigma-Aldrich, $7.5 \mathrm{mmol} \mathrm{L}^{-1}$ ), and $1 \mathrm{~mL} \mathrm{NH} \mathrm{CH}_{3} \mathrm{COO}$ buffer solution (Avantor Performance Materials, $\left.1 \mathrm{~mol} \mathrm{~L}^{-1}, \mathrm{pH} 7\right)$ with investigated extracts $(0.2-$ $1.1 \mathrm{~mL}$, made up to $1.1 \mathrm{~mL}$ with $80 \%$ ethanol) in a test tube. After 30 min incubation, the absorbance of $\mathrm{Cu}$ (I)-neocuproine complex was recorded at $450 \mathrm{~nm}$ against a reagent blank (UVmini 1240 spectrophotometer, Shimadzu, Japan). Results were expressed based on Trolox standard curve, as milligram of Trolox equivalent per $100 \mathrm{~g}$ of honey solids, and per $100 \mathrm{~g}$ of powder solids. Additionally, the contribution of carrier in reducing activity of investigated powders (\%) was calculated.

\section{Gas Chromatography}

A $20 \mathrm{~mL}$ glass vial with samples $(2 \mathrm{~g}$ of feed solution or about $1.2 \mathrm{~g}$ of honey powder solids diluted with $0.8 \mathrm{~g}$ of distilled water to obtain the same solids concentration as in the case of feed solutions) was placed in the oven in temperature of $60^{\circ} \mathrm{C}$ for $20 \mathrm{~min}$. Headspace solid-phase microextraction (HSSPME) method was used to adsorb volatile compounds on the fiber and carry into the GC-MS injector. Volatile compounds from samples with addition of $1 \mu \mathrm{L}$ of internal standard (1,2-dichlorobenzene, $0,01 \%$ solution in methanol, added before closing the bottles) were collected on a SPME fiber divinylbenzene/carboxene/polydimtheylsiloxane (DVB/ CAR/PDMS from Supelco (Bellefonte, PA, USA) at $60^{\circ} \mathrm{C}$ for $5 \mathrm{~min}$. ZB WAX plus $(30 \mathrm{~m} \times 0.25 \mathrm{~mm} \times 0.25 \mu \mathrm{m})$ capillary column Phenomenex (Torrance, CA, USA) was used to separate volatile compounds. Desorption of the volatile compounds was performed in the injector at $250{ }^{\circ} \mathrm{C}$ for $2 \mathrm{~min}$. Helium was used as a carrier gas at a flow rate of $1.59 \mathrm{~mL} \mathrm{~min}^{-1}$. The column temperature was programmed as follows: $60{ }^{\circ} \mathrm{C}$, subsequent increase to $200{ }^{\circ} \mathrm{C}$ at the rate of $3{ }^{\circ} \mathrm{C} / \mathrm{min}$, second increase to $250^{\circ} \mathrm{C}$ at the rate of $3{ }^{\circ} \mathrm{C} / \mathrm{min}$. The interface temperature for GC-MS was $230{ }^{\circ} \mathrm{C}$. Temperature of ion source was $250^{\circ} \mathrm{C}$; ionization energy was $70 \mathrm{~V}$. The total ion monitoring (TIC) was used to detect volatile compounds $(\mathrm{m} / \mathrm{z}$ ranged $35-500)$. The internal standard 1,2-dichlorobenzene was used to semi-quantify volatile compounds. Identification of volatile compounds was made on the basis of mass spectral libraries (NIST 47, NIST 147, and Wiley 175). Three replicates per each sample were analyzed.

\section{FTIR}

Measurements of infrared spectra for the analyzed samples were conducted with the use of a Varian 670-IR FTIR spectrometer. ATR (attenuated total reflection) attachment was used in the form of a $\mathrm{ZnSe}$ crystal with adequate geometry (truncated at $45^{\circ}$ ) to ensure 20 -fold internal reflection of the absorbed beam. During the measurement, 16 scans were registered and subsequently, the program averaged the results for all spectra. Prior to the measurement, the ZnSe crystal was cleaned using ultra-clear solvents by Sigma-Aldrich. Prior to $(1 \mathrm{~h})$ and during the experiment, the measurement chamber was kept in an inert $\mathrm{N}_{2}$ atmosphere. Spectral measurements were recorded in the region from 500 to $4000 \mathrm{~cm}^{-1}$ at the resolution of $1 \mathrm{~cm}^{-1}$. The spectra were analyzed and processed with the use of Grams/AI software (ThermoGalactic Industries, USA). All the spectra were measured at $23{ }^{\circ} \mathrm{C}$ (Fig. 1).

\section{Statistical Methods}

The assays were carried out in triplicate and the results are expressed as mean values and standard deviation (SD). The statistical differences were verified through one-way analysis of variance (ANOVA) followed by Tukey's honestly significant difference test with $a=0.05$. Analysis were done using software STATISTICA v.13.1 (Dell Inc., USA).

\section{Results and Discussion}

\section{Water Content}

The application of dehumidified air as a drying agent for spray drying was the efficient method to obtain powdered honey. The water content in powder was between 1.0 and $1.8 \%$, what was the indicator of well-established drying parameters. The obtained values were even lower than usually presented in the case of traditional high-temperature honey spray drying. (Nurhadi et al. 2012), Shi et al. (2013), Samborska et al. (2015), and Suhag and Nanda (2016b) presented a typical water content in honey powder in the range from 2.3 to $8.6 \%$. Water content was determined as a basic parameter characterizing the obtained powders, because the content of investigated bio-compounds was expressed in relation to honey solids and powder solids. 
Fig. 1 Fourier transform infrared (FTIR) spectra of honey powder samples investigated in the region from 500 to $4000 \mathrm{~cm}^{-1}$

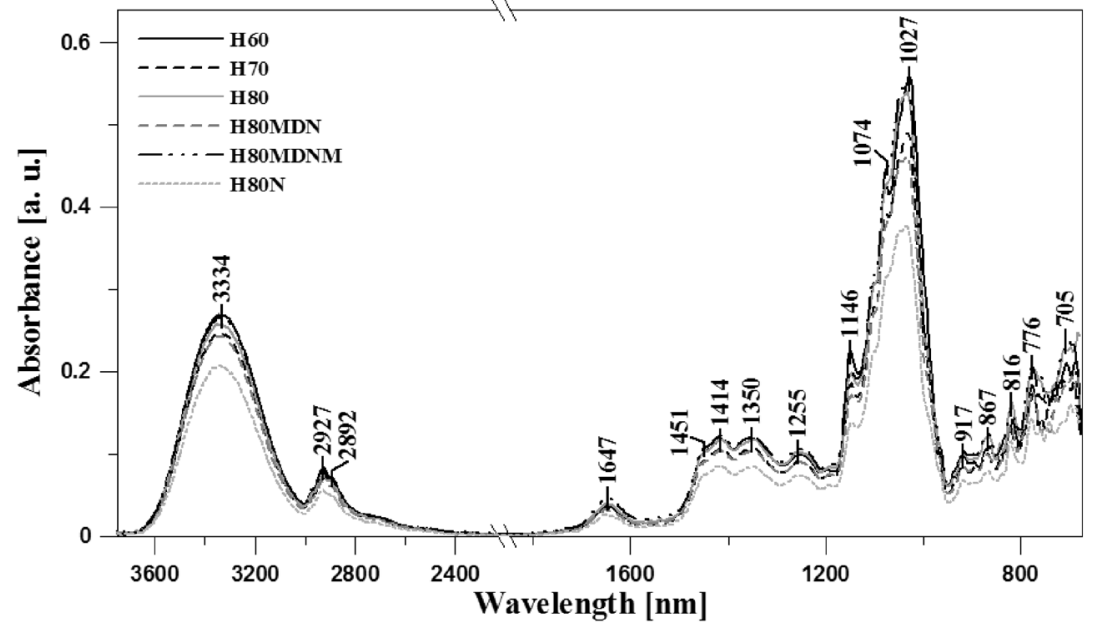

\section{Total Phenolic Content}

Rapeseed honey investigated in the current work contained

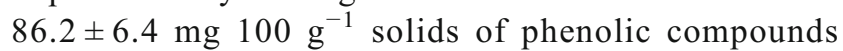
(Table 2). Similar TPC values were reported (Ciappini and Stoppani 2014) in eucalyptus and clover honeys (40.3 to $193.0 \mathrm{mg} \mathrm{GAE} \cdot 100 \mathrm{~g} \mathrm{~g}^{-1}$ ), and (Meda et al. 2005) in Burkina Fasan honey (32.59 to $114.75 \mathrm{mg}$ GAE $100 \mathrm{~g}^{-1}$ ).

Phenolics are generally sensitive to adverse environmental conditions, and are easily degraded during high-temperature processing, including spray drying (Fang and Bhandari 2011; Suhag and Nanda 2016a). Suhag and Nanda (2015) presented TPC values of honey powder enriched with anola and basil extract, obtained by spray drying, between 61.43 and $63.27 \mathrm{mg} \mathrm{GAE} 100 \mathrm{~g}^{-1}$. Inlet temperature (in the range from

Table 2 Total phenolic content (TPC) and antioxidant activity (determined as DPPH and CUPRAC) of rapeseed honey $\mathrm{H}$, maltodextrin $\mathrm{M}$, nutriose $\mathrm{N}$, and honey powders obtained after dehumidified air spray
160 to $180{ }^{\circ} \mathrm{C}$ ) had significant negative linear effect on the TPC as a result of the destruction of phenolic compounds or alternation in their molecular structure at increased temperature. Tonon et al. (2009) presented the decrease of TPC of açai (Euterpe oleracea Mart.) juice after spray drying at inlet/outlet air temperature of $140 / 78{ }^{\circ} \mathrm{C}$ with the addition of different carrier agents. Waterhouse et al. (2017) examined TPC of blueberry waste material extract with addition of alginate or inulin spray-dried at inlet air temperature $150{ }^{\circ} \mathrm{C}$. TPC after drying decreased form $3655.42 \pm 6$ to $28.23 \pm 0.16 \mathrm{~g} \mathrm{GEA} \mathrm{g}^{-1}$. On the contrary, there are also examples of increased TPC after heat treatment of various food products: green pepper, green beans, spinach (Turkmen et al. 2005), or onion powder (Sharma et al. 2015). This increase is attributed to the liberation of phenolic compounds by the cleaving of the esterified and glycosylated

drying with maltodextrin $(\mathrm{H} 60 \mathrm{M}, \mathrm{H} 70 \mathrm{M}, \mathrm{H} 80 \mathrm{M})$, nutriose $(\mathrm{H} 80 \mathrm{~N})$, the mixture of both carriers (H80MN), and the use of skimmed milk as water substitute for feed solution preparation (H80MNm)

\begin{tabular}{|c|c|c|c|c|c|c|c|c|}
\hline & \multicolumn{2}{|l|}{ ТPC } & \multicolumn{3}{|l|}{ DPPH } & \multicolumn{2}{|l|}{ CUPRAC } & \multirow[b]{2}{*}{$\begin{array}{l}\mathrm{CC} \\
(\%)\end{array}$} \\
\hline & $\begin{array}{l}\mathrm{mg} \mathrm{GA} \cdot 100 \mathrm{~g}^{-1} \\
\text { solids }\end{array}$ & $\begin{array}{l}\mathrm{mg} \mathrm{GA} \cdot 100 \mathrm{~g}^{-1} \\
\text { honey solids }\end{array}$ & $\begin{array}{l}\operatorname{mg} \operatorname{Trx} \cdot 100 \mathrm{~g} \\
{ }^{-1} \text { solids }\end{array}$ & $\begin{array}{l}\operatorname{mg} \operatorname{Tr} x \cdot 100 \mathrm{~g}^{-1} \\
\text { honey solids }\end{array}$ & $\begin{array}{l}\mathrm{CC}^{*} \\
(\%)\end{array}$ & $\begin{array}{l}\mu \mathrm{mol} \text { Trx } \cdot 100 \mathrm{~g}^{-1} \\
\text { solids }\end{array}$ & $\begin{array}{l}\mu \mathrm{mol} \text { Trx } \cdot 100 \mathrm{~g}^{-1} \\
\text { honey solids }\end{array}$ & \\
\hline $\mathrm{H}$ & $86.2 \pm 6.4^{\mathrm{d}}$ & $86.2 \pm 6.4^{\mathrm{a}}$ & $12.2 \pm 0.2^{\mathrm{g}}$ & $12.2 \pm 0.2^{\mathrm{a}}$ & - & $154.7 \pm 3.3^{\mathrm{e}}$ & $154.7 \pm 3.3^{\mathrm{a}}$ & - \\
\hline M & - & - & $0.2 \pm 0.1^{\mathrm{a}}$ & - & 100 & nd & - & 100 \\
\hline $\mathrm{N}$ & - & - & $0.4 \pm 0.0^{\mathrm{a}}$ & - & 100 & $22.3 \pm 1.0^{\mathrm{a}}$ & - & 100 \\
\hline H60M & $62.0 \pm 4.5^{\mathrm{a}}$ & $108.3 \pm 7.8^{\mathrm{b}}$ & $7.7 \pm 0.5^{\mathrm{b}}$ & $13.4 \pm 0.9^{\mathrm{b}}$ & 1.1 & $109.0 \pm 4.0^{\mathrm{b}}$ & $190.4 \pm 7.0^{\mathrm{d}}$ & nd \\
\hline H70M & $64.8 \pm 5.2^{\mathrm{ab}}$ & $95.9 \pm 7.7^{\mathrm{ab}}$ & $9.0 \pm 0.3^{c}$ & $13.3 \pm 0.4^{\mathrm{b}}$ & 0.7 & $106.8 \pm 1.9^{\mathrm{b}}$ & $158.1 \pm 2.8^{\mathrm{ab}}$ & nd \\
\hline H80M & $72.4 \pm 5.4^{\mathrm{abc}}$ & $92.7 \pm 6.9^{\mathrm{ab}}$ & $10.5 \pm 0.3^{\mathrm{e}}$ & $13.5 \pm 0.4^{\mathrm{b}}$ & 0.4 & $129.4 \pm 3.8^{\mathrm{c}}$ & $165.6 \pm 4.8^{\mathrm{b}}$ & nd \\
\hline $\mathrm{H} 80 \mathrm{~N}$ & $74.4 \pm 5.7^{\mathrm{bcd}}$ & $95.3 \pm 7.2^{\mathrm{ab}}$ & $9.5 \pm 0.1^{\mathrm{cd}}$ & $12.2 \pm 0.1^{\mathrm{a}}$ & 0.9 & $139.5 \pm 4.0^{\mathrm{d}}$ & $178.5 \pm 5.1^{\mathrm{c}}$ & 3.5 \\
\hline H80MN & $76.4 \pm 6.6^{\mathrm{bcd}}$ & $97.8 \pm 8.5^{\mathrm{ab}}$ & $10.0 \pm 0.1^{\mathrm{de}}$ & $12.8 \pm 0.1^{\mathrm{ab}}$ & 0.6 & $144.4 \pm 4.5^{\mathrm{d}}$ & $184.9 \pm 5.7^{\mathrm{cd}}$ & 1.7 \\
\hline H80MNm & $78.5 \pm 3.7^{\mathrm{cd}}$ & $100.5 \pm 4.7^{\mathrm{ab}}$ & $11.5 \pm 0.1^{\mathrm{f}}$ & $14.8 \pm 0.2^{\mathrm{c}}$ & 0.5 & $219.6 \pm 2.1^{\mathrm{f}}$ & $281.1 \pm 2.6^{\mathrm{e}}$ & 1.1 \\
\hline
\end{tabular}

* CC-carrier contribution in DPPH and CUPRAC antioxidant activity

${ }^{\mathrm{a}-\mathrm{e}}$ differences between mean values followed by the same letters in columns were statistically not significant $(p>0.05)$

$n d$ not detectable 
bond (Sharma et al. 2015). TPC in the investigated honey powders, expressed as mg GA $100 \mathrm{~g}^{-1}$ of honey solids, was also higher than in pure honey, but only in case of $H 60 \mathrm{M}$, the difference was statistically significant $(p<0.05)$. Honey drying in the presence of carriers can be treated as microencapsulation, which is often applied to protect food ingredients against deterioration (Shahidi and Han 1993). As compared to all microencapsulation techniques and methods, the spray drying process is relatively inexpensive, straightforward, and well established (Murugesan and Orsat 2012). Fang and Bhandari (2011) investigated the effect of spray drying on the retention of phenolic compounds in bayberry juice. The retention of TPC after drying at inlet/outlet air temperature $150 / 80{ }^{\circ} \mathrm{C}$ was $96 \pm 1 \%$, what was explained by rather minor thermal stress during very fast evaporation (contact time $<1 \mathrm{~s}$ ). As one reason of degradation during drying can be also oxidation, thus the bounding to an encapsulant polymer has a protective potential (Sun-Waterhouse et al. 2013).

However, as was presented above, during traditional hightemperature spray drying, also higher deterioration of TPC was noted before (Suhag and Nanda 2015; Tonon et al. 2009). So, as the operating temperatures are very important for the spray drying of heat sensitive materials, from the point of view of honey TPC retention during spray drying, it is especially important that DASD can be performed at low temperature. Moreover, it was also noted that the decrease of carrier content resulted in lower increase of TPC expressed per honey solids (samples H60-H80), suggesting a positive effect of the presence of carrier in honey powder.

As far as TPC expressed as mg GA $100 \mathrm{~g}^{-1}$ of powder solids is concerned, it depended on honey and carrier content in the powder. Maltodextrin-based powders containing 60,70, and $80 \%$ of honey solids (H60M, H70M, H80M) had significantly lower TPC than pure honey, while for the rest of samples the difference in TPC content comparing to pure honey was statistically not significant $(p>0.05)$. Due to the increase of honey TPC after drying (expressed per honey solids), with simultaneous reduction of carrier content in powders, powders $\mathrm{H} 80 \mathrm{~N}, \mathrm{H} 80 \mathrm{MN}$, and H80MNm had TPC at the same level (expressed per powder solids) as pure honey (difference statistically not significant). It was not observed in M-based powders, and can suggest better properties of $\mathrm{N}$ as protective agent for phenolic compounds. In the work presented by BelščakCvitanović et al. (2015), inulin was also effective microencapsulant, enabling significantly higher product yield obtained by spray drying, when compared to plain spray-dried green tea extract.

\section{DPPH and CUPRAC Antioxidant Activity}

Antioxidant activity (AOA) was determined as DPPH radical scavenging assay and by CUPRAC method. DPPH method is widely used to investigate the free radical-scavenging activity of several natural products (Ahn et al. 2007). DPPH is a stable free radical and any molecule that can donate an electron or hydrogen to DPPH can react with it and bleach the DPPH absorption at $517 \mathrm{~nm}$ (Bakchiche et al. 2017). In cupric reducing antioxidant power (CUPRAC) assay, $\mathrm{Cu}$ (II) is reduced to $\mathrm{Cu}(\mathrm{I})$ through the action of electron-donating antioxidants (Pisoschi and Negulescu 2012). The values of DPPH and CUPRAC antioxidant activity were expressed in relation to powder solids and honey solids (Table 2).

Pure honey DPPH $\left(12.2 \pm 0.2 \mathrm{mg}\right.$ Trx $100 \mathrm{~g}^{-1}$ solids $)$ and CUPRAC antioxidant activity $\left(154.7 \pm 3.3 \mu \mathrm{mol}\right.$ Trx $100 \mathrm{~g}^{-1}$ solids) was in a range typical for monofloral honeys, i.e., cornflower (Kuś et al. 2014a) and heather honey from Poland (Kuś et al. 2014b), acacia honey from Marocco (Petretto et al. 2016). As in the case of TPC, varied results related to the effect of heat treatment on AOA of food products were presented in the literature; both the increase and the decrease were noted. During heat treatment of green pepper, squash, broccoli, green peas, spinach (Turkmen et al. 2005), and powdered onion (Sharma et al. 2015) AOA significantly increased. This growth was caused by the enhancement of the antioxidant properties of naturally occurring compounds (caused by structure alteration) or the formation of novel compounds such as Maillard reaction products that have antioxidant activity (Nicoli et al. 1999; Sharma et al. 2015). However, traditional high-temperature spray drying seems to be more intensive thermal process, despite very short drying time, because several authors reported the deterioration of AOA after such processing. According to Suhag and Nanda (2016a), honey DPPH antioxidant activity is susceptible for thermal degradation during spray drying. A significant loss of antioxidant activity was also presented in case of hightemperature spray drying of gac fruit juice (Kha et al. 2010), and açai (Euterpe oleracea Mart.) juice (Tonon et al. 2010). Basing on literature reports and our results, it may be hypothesized that lower heat dose applied during spray drying by dehumidified air provides the energy necessary for advantageous phenolic alterations, while higher heat transfer during traditional spray drying leads to diminish of honey bioactivity. Thus, the reduction of spray drying temperature is of vital significance from the point of view of honey AOA retention in powdered product. In the current work, due to the application of dehumidified air, spray drying temperature was decreased. Such drying conditions did not cause the deterioration of DPPH and CUPRAC antioxidant activity-the values obtained for honey present in powders were even significantly higher $(p<0.05)$ than in case of pure honey (Table 2). This phenomenon was not connected with the contribution of carriers $(\mathrm{M}$ and $\mathrm{N})$ in the investigated activity, because these higher values were expressed per mass of honey solids. The increase was probably caused by the abovementioned mechanisms known from the literature. Moreover, the use of $\mathrm{M}$ seems to favor the transformations that led to better electron- 
donating ability of the antioxidants (higher reducing power). Nevertheless, among all the constituents of powders other than honey, the introduction of milk was the key factor in terms of high AOA in the products obtained. Milk is a source of antioxidants as well and their contribution cannot be excluded, but taking into consideration their concentration and the level of milk addition, obtained results also indicate the protective effect of its constituents during honey processing.

Values of AOA expressed in regard to powder solids were significantly lower $(p<0.05)$ than for pure honey (except $\mathrm{H} 80 \mathrm{MNm}$ ) due to the presence of carriers, which exhibited very low antioxidant activity ( $\mathrm{M}$ did not have any CUPRAC activity). Carrier contribution did not exceed $1.1 \%$ in case of DPPH, and $3.5 \%$ in case of CUPRAC. However, skimmed milk used as water substitute for feed solution preparation affected AOA; the values for $\mathrm{H} 80 \mathrm{MNm}$ were significantly higher $(p<0.05)$ than for the rest of powders, as well as for pure honey.

\section{Volatile Compounds}

In all analyzed samples, the following groups of volatiles were detected: acids, alcohols, aldehydes, hydrocarbons, ketones, esters, furanes, terpenes, and sulfur compounds. More than 100 different compounds were identified in feed solutions, and a total of 85 compounds were identified in the samples of reconstituted honey powders. Number of individual volatile compounds $(\mathrm{N})$ in particular samples, as well as the total volatile compounds concentration (VCC), which were determined in feed solutions and reconstituted powders is presented in Table 3.

Twelve compounds out of 102 were found in all samples (both in feed solutions and reconstituted powders). Those compounds were benzaldehyde, dimethyl sulfide, nonanal, acetic acid, furfural, hexadecanoic acid methyl ester, isopropyl myristate, lilac aldehyde B, benzyl alcohol, 2,3-butanediol, and 2-methyl-propanoic acid (Figs. 2-7). Kuś and van Ruth (2015) used headspace and proton transfer reaction mass spectrometry to distinguish the floral origin of Polish honeys. They reported that the most abundant component in rapeseed honey were acetic acid, dimethyl sulfide, furfural, and benzaldehyde (also detected in this study). Radovic et al. (2001) confirmed authenticity of rapeseed honey due to the presence of dimethyl sulfide; moreover, they concluded that this component can be used as botanical marker in the determination of this type of honey.

VCC in feed solutions reached from 1.5 to $6.1 \mathrm{mg} \mathrm{kg}^{-1}$ solids. It depended on honey content in sample solids. Among samples containing $80 \%$ of honey solids, the sample in which milk was used as a solvent contained significantly higher amount of volatile compounds. Samples of reconstituted honey powders were characterized by more intensive aroma than feed solutions before drying, except variants $\mathrm{H} 70 \mathrm{M}$ (value after drying was higher, but the difference was statistically not significant) and H80M (value after drying was lower, but the difference was statistically not significant).

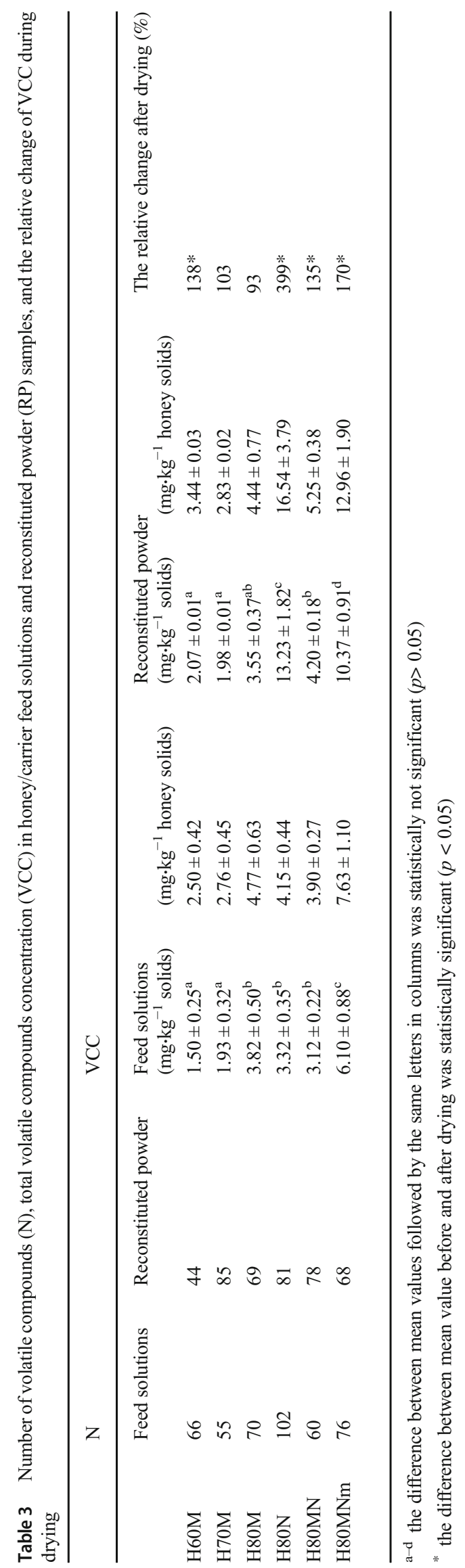




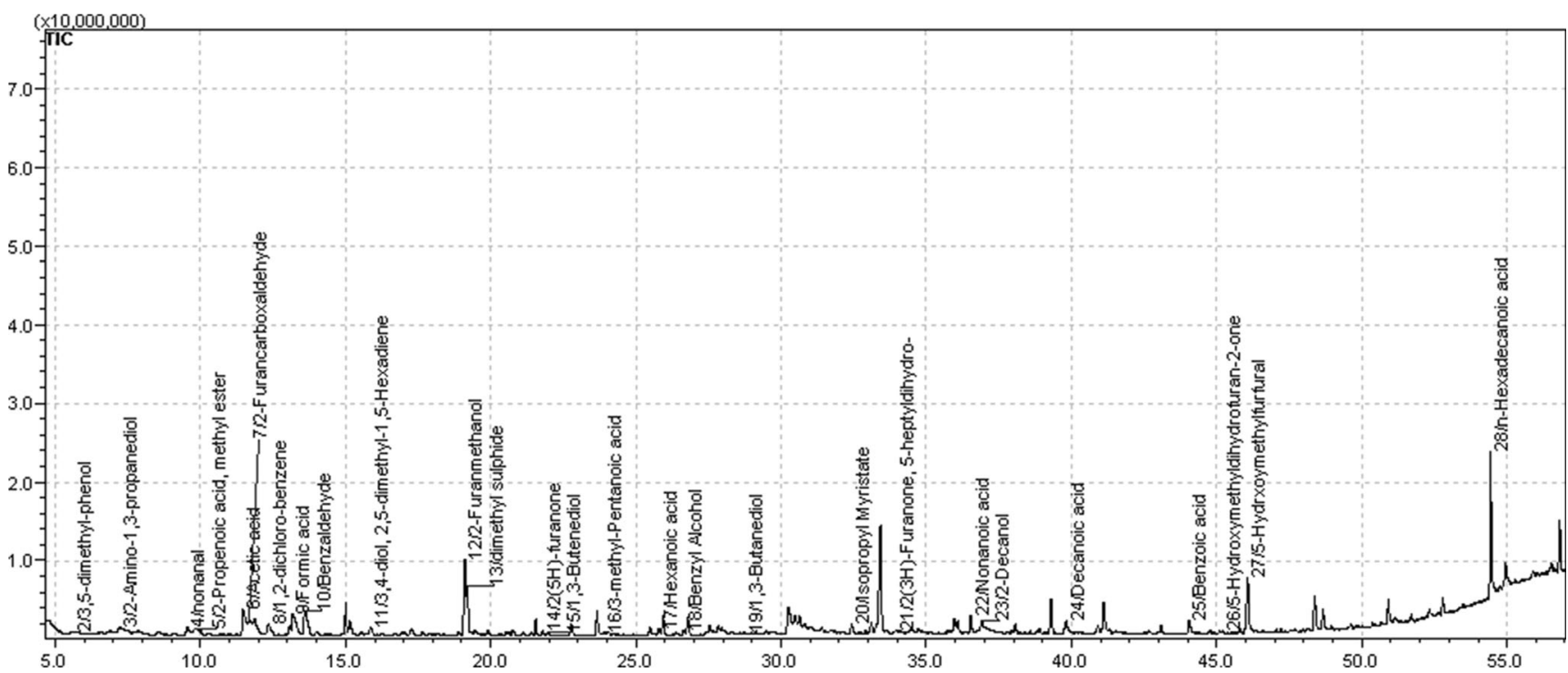

Fig. 2 TIC chromatogram of volatile compounds determined in honey powder H60M

The most intensive aroma was reported in sample with NUTRIOSE (H80N) and skimmed milk (H80MNm). According to Manyi-Loh et al. (2011), changes in heated or stored honey can be attributed to two principal causes: compounds that are heat labile and may be destroyed, and volatile compounds produced by non-enzymatic browning (Maillard reaction). Spray drying, even at high temperature, is one of the most popular methods for flavors microencapsulation. The possible changes in aroma profile during this hightemperature processing are recognized as favorable, creating desirable fragrance. Chemical reactions during drying create exceptional fragnance bouquet. Jedlińska et al. (2018), who spray-dried vanilla and raspberry aromas, found over $100 \%$ content of some compounds (isoamyl acetate, diacetyl, cis +3 hexenyl butyrate) compared to the feed solution. It was explained by high temperature in the drying chamber. Penbunditkul et al. (2012) determined over $100 \%$ linalool content in microencapsulated bergamot oil, what was explained by its formation from linalool acetate. Moreover, although only present in low concentrations, volatile compounds could contribute to biomedical activities of honey, especially the antioxidant effect due to their natural radicalscavenging potential (Manyi-Loh et al. 2011). Spray drying process led to the higher VCC due to the formation of new aroma compounds (e.g., 3-methyl-pentanoic acid, 4oxopentanoic acid, 5-methyl-2-furancarboxaldehyde), or the increase of the concentration of aroma compounds (e.g., 2furanmethanol, oxime-, methoxyphenyl, benzaldehyde).

In the sample obtained with the addition of NUTRIOSE $(\mathrm{H} 80 \mathrm{~N})$ after spray drying, the total VCC was 4-fold higher

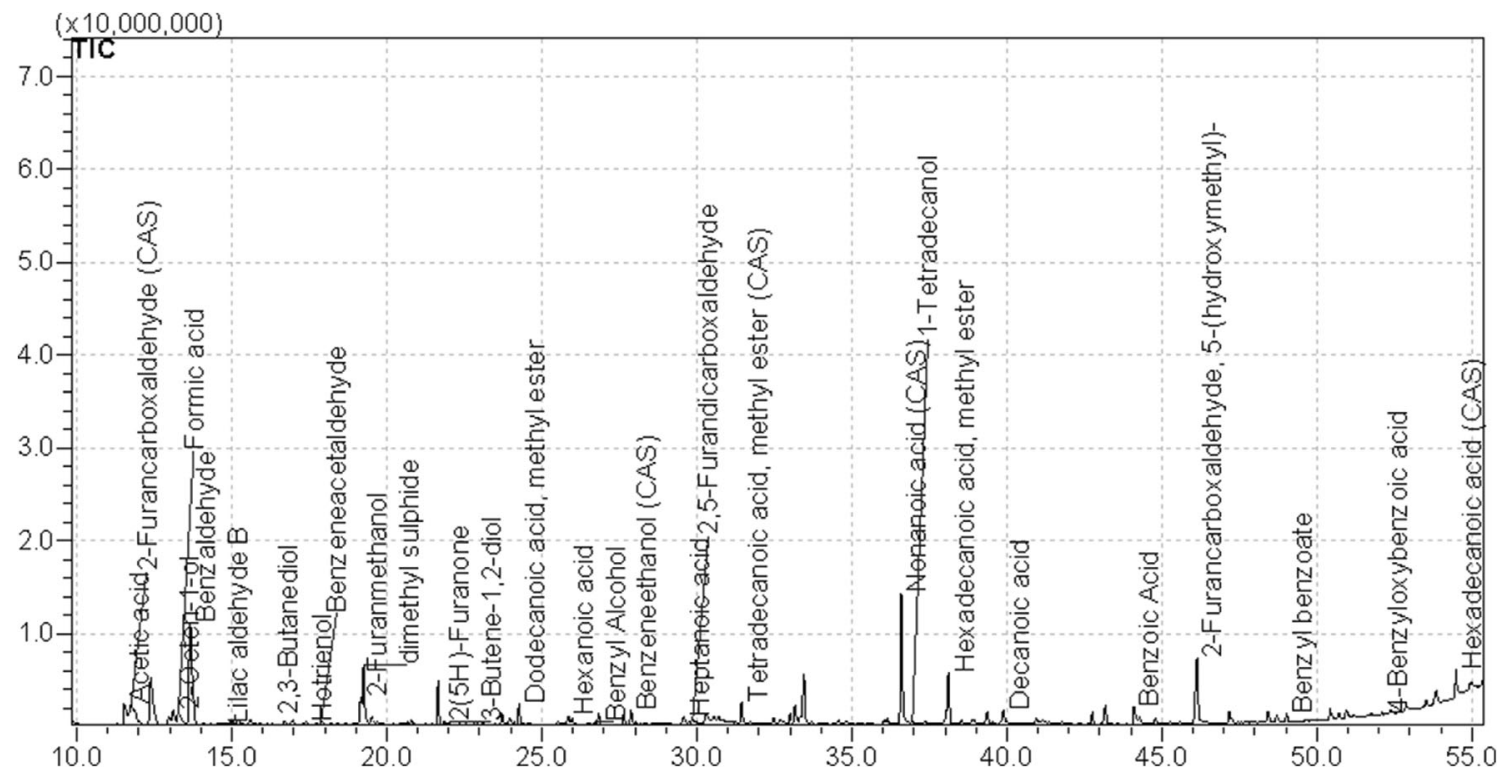

Fig. 3 TIC chromatogram of volatile compounds determined in honey powder H70M 


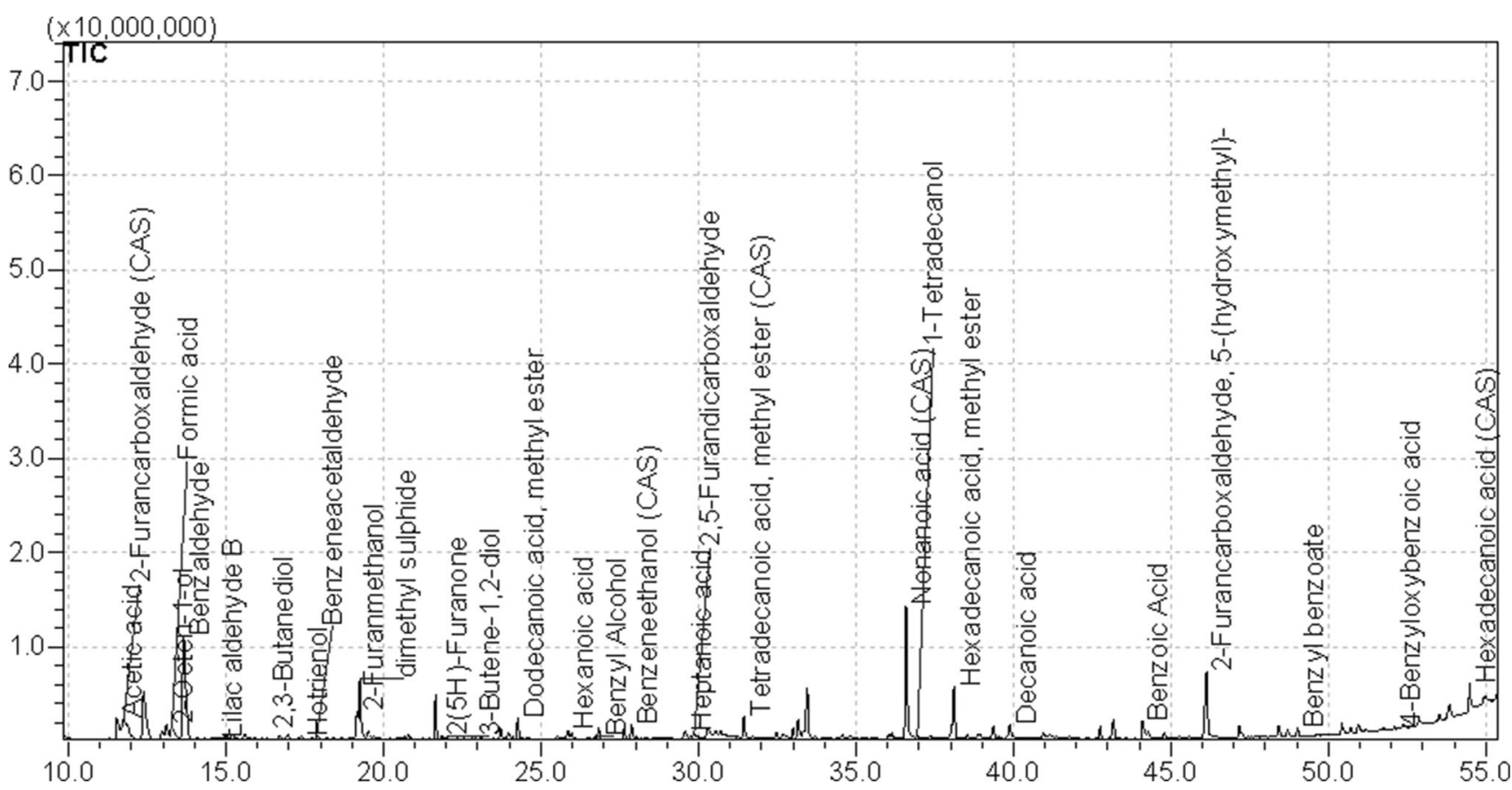

Fig. 4 TIC chromatogram of volatile compounds determined in honey powder H80M

than in the feed solution, which means that aroma of this powder was the most intensive. All of the powders that contained NUTRIOSE were characterized by the higher content of the volatile compounds comparing to the feed solutions. Reconstituted powders with addition of maltodextrin were characterized by higher VCC in comparison to solutions only in one variant, $\mathrm{H} 60 \mathrm{M}$, even though that this sample contained the lowest amount of honey. In variants $\mathrm{H} 70 \mathrm{M}$ and $\mathrm{H} 80 \mathrm{M}$, the increase of VCC after drying was not observed. The same level of VCC increase as in H60M sample was determined in $\mathrm{H} 80 \mathrm{MN}$ sample, containing the mixture of both carriers. The application of skimmed milk as a solvent did not result in a such high increase of VCC after drying as the use of NUTRIOSE, but it was higher than in the corresponding variant $\mathrm{H} 80 \mathrm{MN}$ in which water was used as a solvent.

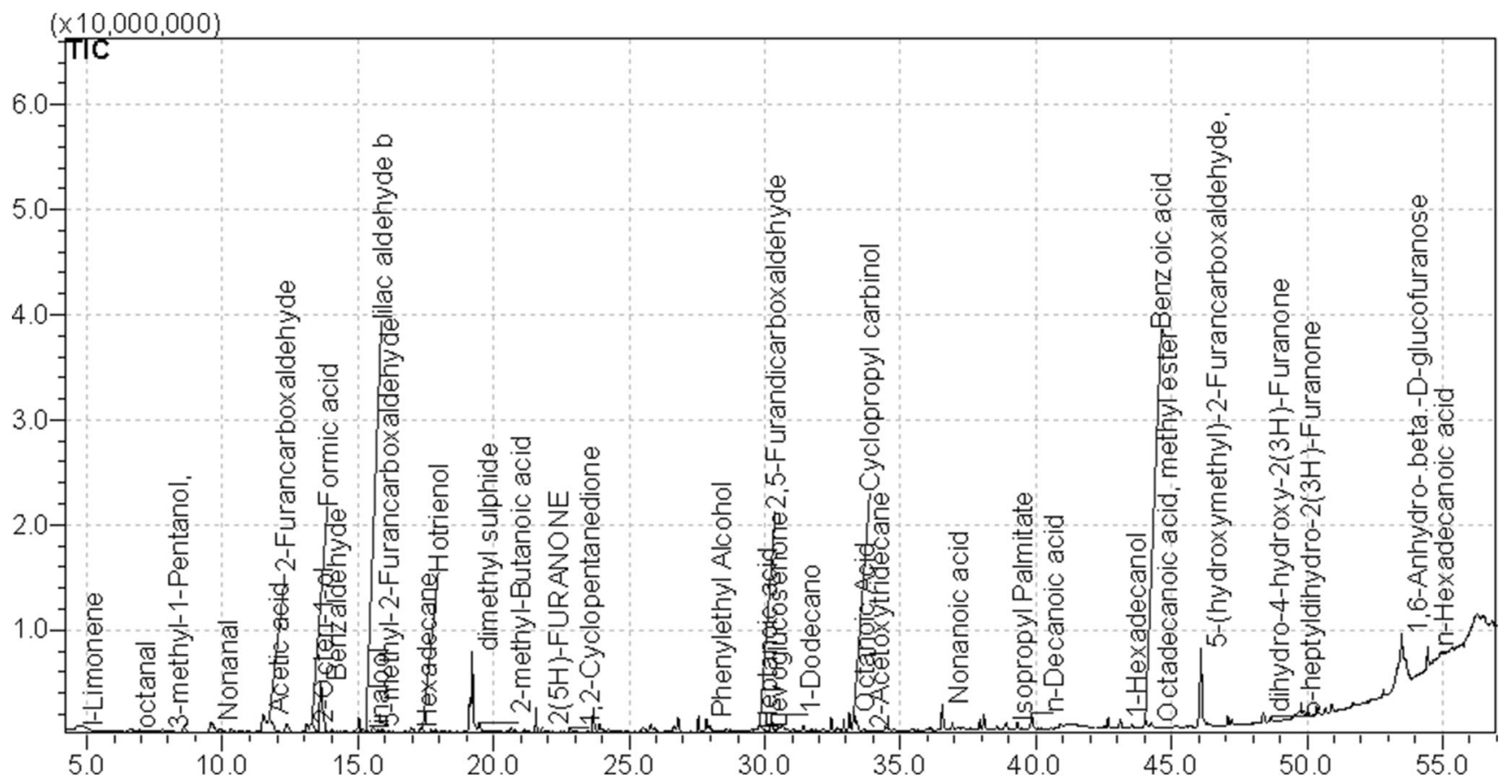

Fig. 5 TIC chromatogram of volatile compounds determined in honey powder $\mathrm{H} 80 \mathrm{~N}$ 


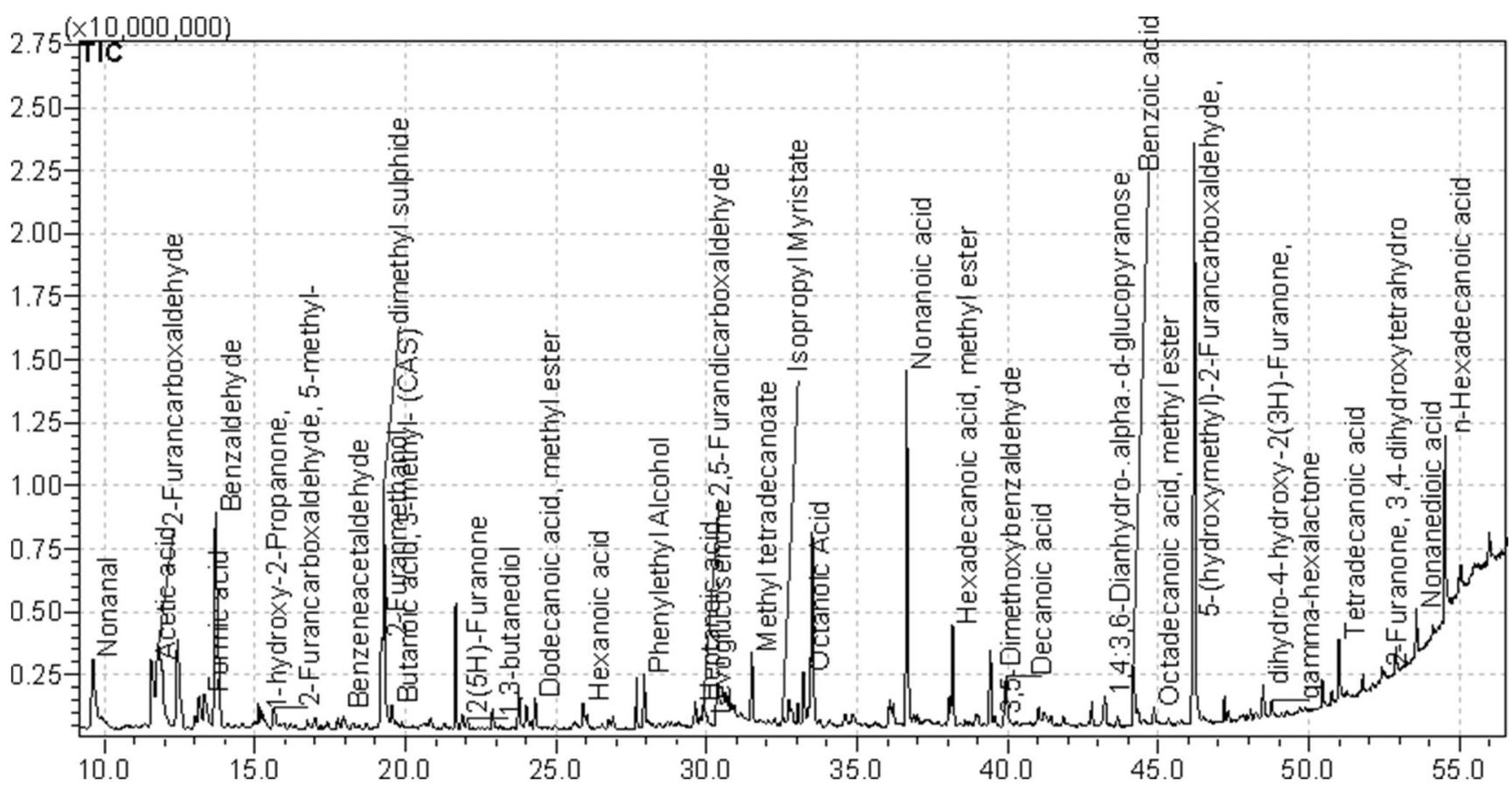

Fig. 6 TIC chromatogram of volatile compounds determined in honey powder H80MN

One of the volatile compounds present in the investigated samples (except H80MNm) was 5-hydroxymethylfurfural (5HMF), one of the best markers of thermal processing of honey (Aguilar et al. 2016). European Union Directive 2001/110/EC recommends limit of $40 \mathrm{mg}$ of 5-HMF per kilogram of honey (with a few exceptions, $80 \mathrm{mg} \mathrm{kg}^{-1}$ for honey coming from regions with tropical temperatures and $15 \mathrm{mg} \mathrm{kg}^{-1}$ for honey with low enzymatic levels). Veríssimo et al. (2017) used headspace-solid-phase microextraction coupled with a polyoxometalate-coated piezoelectric quartz crystal for the determination of 5-HMF in honey. The method used in our study was not the same, but enabled to semi-quantify 5-HMF content, which was below $1 \mathrm{mg} \mathrm{kg}^{-1}$ in every sample. It proofs that conditions used for spray drying did not change the quality of honey. Samborska and Czelejewska (2014) studied the effect of high temperature $\left(180 / 70{ }^{\circ} \mathrm{C}\right)$ spray

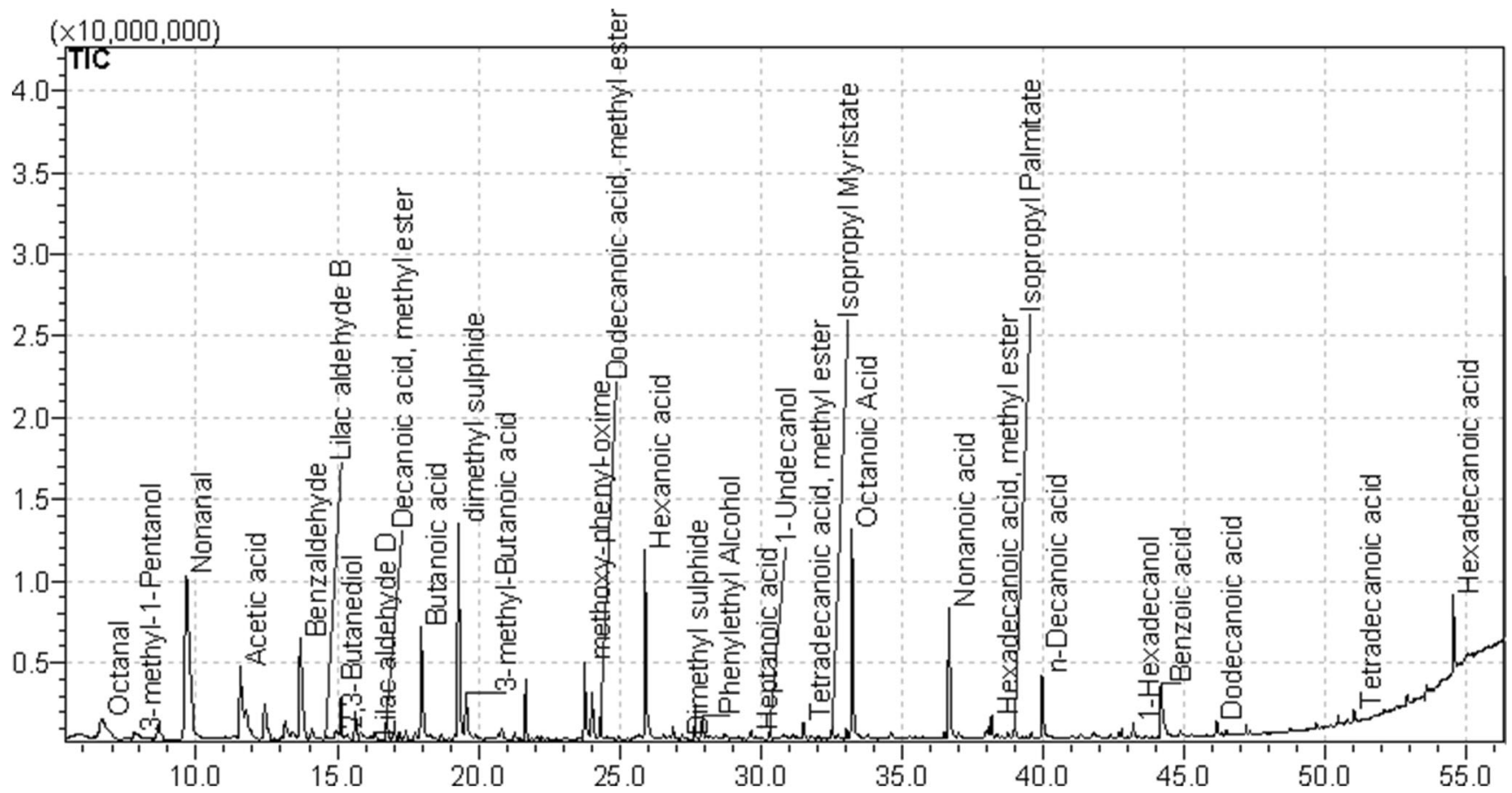

Fig. 7 TIC chromatogram of volatile compounds determined in honey powder H80MNm 
Table 4 The location of the maxima of absorption bands FTIR with arrangement of appropriate vibration in terms of spectral $3750-690 \mathrm{~cm}^{-1}$

Position of bands $\left(\mathrm{cm}^{-1}\right) \quad$ Type and origin of vibrations

\begin{tabular}{|c|c|c|c|c|c|c|}
\hline H60 & $\mathrm{H} 70$ & $\mathrm{H} 80$ & H80MDN & H80MDNm & $\mathrm{H} 80 \mathrm{~N}$ & \\
\hline 3335 & 3339 & 3330 & 3330 & 3330 & 3339 & $v(\mathrm{O}-\mathrm{H})$ in $\mathrm{H}_{2} \mathrm{O}$ \\
\hline $\begin{array}{l}2936 \\
2888\end{array}$ & $\begin{array}{l}2936 \\
2893\end{array}$ & $\begin{array}{l}2927 \\
2884\end{array}$ & $\begin{array}{l}2931 \\
2893\end{array}$ & $\begin{array}{l}2931 \\
2893\end{array}$ & $\begin{array}{l}2931 \\
2880\end{array}$ & $v(\mathrm{C}-\mathrm{H})$ in $\mathrm{CH}_{2}$ and $\mathrm{CH}_{3}$ group or/and $v\left(\mathrm{NH}_{3}\right)$ of free amino acids \\
\hline 2730 & 2734 & 2717 & 2734 & 2735 & 2721 & \\
\hline 1648 & 1648 & 1648 & 1650 & 1648 & 1652 & $\delta(\mathrm{O}-\mathrm{H})$ in $\mathrm{H}_{2} \mathrm{O}$ \\
\hline 1456 & 1454 & 1449 & 1449 & 1449 & 1454 & $\delta(-\mathrm{O}-\mathrm{CH})$ and $\delta(-\mathrm{C}-\mathrm{C}-\mathrm{H})$ \\
\hline 1416 & 1416 & 1417 & 1414 & 1412 & 1414 & $\delta(\mathrm{O}-\mathrm{H})$ in $\mathrm{C}-\mathrm{OH}$ group $+\delta(\mathrm{C}-\mathrm{H})$ in the alkenes \\
\hline 1351 & 1355 & 1350 & 1350 & 1351 & 1350 & $\delta(-\mathrm{OH})$ in $\mathrm{C}-\mathrm{OH}$ group \\
\hline $\begin{array}{l}1251 \\
1199\end{array}$ & $\begin{array}{l}1256 \\
1194\end{array}$ & $\begin{array}{l}1256 \\
1194\end{array}$ & $\begin{array}{l}1253 \\
1194\end{array}$ & $\begin{array}{l}1251 \\
1194\end{array}$ & $\begin{array}{l}1256 \\
1187\end{array}$ & $v(\mathrm{C}-\mathrm{H})$ in carbohydrates or/and $v(\mathrm{C}-\mathrm{O})$ in carbohydrates \\
\hline 1152 & 1150 & 1148 & 1146 & 1143 & 1143 & $v(\mathrm{C}-\mathrm{H})$ in carbohydrates or/and $v(\mathrm{C}-\mathrm{O})$ in carbohydrates \\
\hline 1099 & 1106 & 1104 & 1101 & 1100 & 1099 & $v(\mathrm{C}-\mathrm{O})$ in $\mathrm{C}-\mathrm{O}-\mathrm{C}$ group \\
\hline $\begin{array}{l}1079 \\
1031\end{array}$ & $\begin{array}{l}1075 \\
1033\end{array}$ & $\begin{array}{l}1077 \\
1035\end{array}$ & $\begin{array}{l}1071 \\
1049 / 1031\end{array}$ & $\begin{array}{l}1073 \\
1038\end{array}$ & $\begin{array}{l}1071 \\
1035\end{array}$ & $v(\mathrm{C}-\mathrm{O})$ in $\mathrm{C}-\mathrm{OH}$ group or $v(\mathrm{C}-\mathrm{C})$ in the carbohydrate structure $\delta(\mathrm{C}-\mathrm{H})$ \\
\hline 919 & 923 & 916 & 921 & 983/916 & 914 & \\
\hline 866 & 868 & 868 & 870 & 864 & 868 & Anomeric region of carbohydrates or $\delta(\mathrm{C}-\mathrm{H})$ (mainly in the structure of sugar) \\
\hline 851 & 820 & 820 & 815 & 817 & 822 & \\
\hline 773 & 773 & 773 & 771 & $776 / 760$ & 778 & \\
\hline 705 & 721 & 705 & 701 & 709 & 735 & \\
\hline 687 & 690 & 683 & - & - & 698 & \\
\hline
\end{tabular}

$\nu$ stretching vibrations, $\delta$ deformation vibrations, $s$ symmetric, as asymmetric, st strong

drying on 5-HMF formation in rapeseed honey using spectrophotometric method. HMF content in the powder obtained with the addition of gum arabic as a carrier, calculated in relation to honey, was over 25 times higher than before drying (1.8 and $47.1 \mathrm{mg} \mathrm{kg}^{-1}$ of honey, fresh sample and spray-dried sample respectively). Thus, low-temperature spray drying conditions applied used in the current work were a good solution to limit HMF formation.

\section{FTIR}

The analyzed samples were also characterized with the use of FTIR spectroscopy. For a clear presentation of bands and their characteristics in Fig. 1 and Table 4 (in the spectral range from 3375 to $675 \mathrm{~cm}^{-1}$ ), the spectra and their key bands were assigned to their respective vibrations.

As observed by Anjos et al. (2015), Kasprzyk et al. (2018), and Svečnjak et al. (2015) in the case of the analyzed samples, the first clearly defined region is positioned at 3600$3000 \mathrm{~cm}^{-1}$ (in our case $3334-3100 \mathrm{~cm}^{-1}$ for all samples Table 4 and Fig. 1) which is characteristic of the stretching vibrations of $-\mathrm{OH}$ groups from carbohydrates, water, and organic acids. The region often also includes the stretching vibrations of carboxylic acids and also the $\mathrm{NH}_{3}$ stretching band of free amino acids. The area is positioned in close vicinity to the stretching vibrations of $\mathrm{C}-\mathrm{H}$ groups (alkyl and aromatic, forming the chemical skeleton of sugars) which in this case occur primarily in the $-\mathrm{CH}_{2}$ and $-\mathrm{CH}_{3}$ groups (symmetric and asymmetric) (Kluczyk et al. 2016; Kamiński et al. 2012; Budziak et al. 2018). Bands with the maximum at approx. $3334 \mathrm{~cm}^{-1}$ are a fairly characteristic contribution originating from carboxylic acids whose somewhat irregular absorption (with a broad $-\mathrm{OH}$ band) enhances the bands of $\mathrm{C}-\mathrm{H}$ stretching vibrations.

The broadening of the - $\mathrm{OH}$ group's stretching vibrations is a product of strong hydrogen bonds present in the dimers of carboxylic acids (Anjos et al. 2015). The vibrations of water molecules additionally correspond to the band with the maximum at approx. $1647 \mathrm{~cm}^{-1}$ that reflects its deformation vibrations. Another important region that was practically invisible in our spectra covers bands with the maxima at 1700 $1600 \mathrm{~cm}^{-1}$ related to the bending vibrations of $-\mathrm{OH}$ from water (strong band) and stretching vibrations of ketone $\mathrm{C}=\mathrm{O}$ functional groups in fructose and $\mathrm{CH}=\mathrm{O}$ aldehyde of glucose (practically invisible, only enhancement of the band with the maximum at $1647 \mathrm{~cm}^{-1}$ ).

A very characteristic, fingerprint region for the analyzed samples includes the rich spectra in the range from 1480 to $700 \mathrm{~cm}^{-1}$. The characteristic vibrations in this region include the stretching vibrations of $\mathrm{C}-\mathrm{O}, \mathrm{C}-\mathrm{C}$, and $\mathrm{C}-\mathrm{H}$ groups and the bending vibrations of $\mathrm{C}-\mathrm{H}$ present in the chemical structure of carbohydrates (Anjos et al. 2015; Kasprzyk et al. 2018) 
(often also from organic acids and carotenes). One should also mention the most interesting vibrations within this range, e.g., the bands at $1451 \mathrm{~cm}^{-1}, 1414 \mathrm{~cm}^{-1}$, and $1350 \mathrm{~cm}^{-1}$. These are characteristic of deformation vibrations of the $\mathrm{O}-\mathrm{CH}$ and $\mathrm{C}-\mathrm{C}-\mathrm{H}$ groups in the carbohydrate structure or $-\mathrm{OH}$ deformation vibrations originating from the $\mathrm{C}-\mathrm{OH}$ group. Bands in the range from 1245 to $1150 \mathrm{~cm}^{-1}$ correspond to the stretching vibrations of $\mathrm{C}-\mathrm{H}$ and $\mathrm{C}-\mathrm{O}$ in the carbohydrate structure. The bands at 1146 and $1027 \mathrm{~cm}^{-1}$ reflect the vibrations of the $\mathrm{C}-\mathrm{O}$ group in $\mathrm{C}-\mathrm{O}-\mathrm{C}$. The regions from 1025 to $930 \mathrm{~cm}^{-1}$ and under $900 \mathrm{~cm}^{-1}$ are, respectively, the stretching vibrations of $\mathrm{C}-\mathrm{O}$ in the $\mathrm{C}-\mathrm{OH}$ group or stretching vibrations of $\mathrm{C}-\mathrm{C}$ in the carbohydrate structure (Kasprzyk et al. 2018; Anjos et al. 2015). The last region at $900-700 \mathrm{~cm}^{-1}$ is characteristic of the anomeric region vibrations in carbohydrates or $\mathrm{C}-\mathrm{H}$ and $\mathrm{C}-\mathrm{C}$ deformation (Kasprzyk et al. 2018). Changes in those bands often indicate bond modifications in sugar fractions.

\section{Conclusions}

1. Low-temperature spray drying with the use of dehumidified air is a good method to obtain honey powder of substantially increased amount of honey (up to $80 \%$ solids) comparing to previous works.

2. Honey powders obtained by this method are characterized by high antioxidant activity and rich aroma. In the case of $80 \%$ honey powders ( $20 \%$ of carrier), these properties were not deteriorated comparing to pure honey before drying. Thus, this level of carrier addition can be treated as optimal from the point of view of bioactive properties retention during low-temperature spray drying. Such low carrier addition is favorable due to the perception of such product as natural. If used as food component, the dose of such honey-rich powder can be reduced comparing to traditional products containing higher amount of carrier (usually not lower than 50\%).

3. The addition of NUTRIOSE as maltodextrin substitution, as well as the application of skimmed milk as water substitution for feed solutions preparation, gives very good results from the point of view of high antioxidant activity and aroma retention. NUTRIOSE can be used as a carrier, instead of traditionally used maltodextrin, for the preparation of added-value honey powder.

4. Low-temperature spray drying with the use of dehumidified air has a positive impact on powder antioxidant activity and aroma. At the same time, the increase of the concentration of the compound with known negative effects on human health (HMF), is not observed.

\section{Compliance with Ethical Standards}

Conflict of Interest The authors declare that they have no conflict of interest.

Open Access This article is distributed under the terms of the Creative Commons Attribution 4.0 International License (http:// creativecommons.org/licenses/by/4.0/), which permits unrestricted use, distribution, and reproduction in any medium, provided you give appropriate credit to the original author(s) and the source, provide a link to the Creative Commons license, and indicate if changes were made.

\section{References}

Aguilar, K., Garvínn, A., Azuara, E., \& Ibarz, A. (2016). Rate-controlling mechanisms in the photo- degradation of 5-hydroxymethylfurfural. Food and Bioprocess Technology, 9(8), 1399-1407. https://doi.org/ 10.1007/s11947-016-1729-7.

Ahn, M. R., Kumazawa, S., Usui,Y., Nakamura, J., Matuska, M., Zhu, F., Nakayama, T. (2007). Antioxidant activity and constituents of propolis collected in various areas of China. Food Chemistry 101, 13831392. https://doi.org/10.1016/j.foodchem.2006.03.045.

Amarowicz, R., Carle, R., Dongowski, G., Durazzo, A., Galensa, R., Kammerer, D., Maiani, G., \& Piskula, M. K. (2009). Influence of postharvest processing and storage on the content of phenolic acids and flavonoids in foods. Molecular Nutrition \& Food Research, 53(S2), S151-S183. https://doi.org/10.1002/mnfr.200700486.

Anjos, O., Campos, M. G., Ruiz, P. C., \& Antunes, P. (2015). Application of FTIR-ATR spectroscopy to the quantification of sugar in honey. Food Chemistry, 169, 218-223. https://doi.org/10.1016/j.foodchem. 2014.07.138.

Apak, R., Güçlü, K., Özyürek, M., \& Çelik, S. (2008). Mechanism of antioxidant capacity assays and the CUPRAC (cupric ion reducing antioxidant capacity) assay. Microchimica Acta, 160, 413-419.

Bakchiche, B., Habati, M., Benmebarek, A., \& Gherib, A. (2017). Total phenolic, flavonoid contents and antioxidant activities of honey and propolis collected from the region of Laghouat (south of Algeria). World News of Natural Sciences, 11, 91-97.

Belščak-Cvitanović, A., Lević, S., Kalušević, A., Špoljarić, I., Đorđević, V., Komes, D., et al. (2015). Efficiency assessment of natural biopolymers as encapsulants of green tea (Camellia sinensis L.) bioactive compounds by spray drying. Food and Bioprocess Technology, 8, 2444-2460. https://doi.org/10.1007/s11947-015-1592-y.

Bobiş, O., Mărghitaş, L., Dezmirean, D. S., Chirilă, F., \& Moritz, R. F. A. (2011). Preliminary studies regarding antioxidant and antimicrobial capacity for different types of Romanian honeys. Animal Science and Biotechnologies, 68(1-2), 91-97.

Boekel, M., Fogliano, V., Pellegrini, N., Stanton, C., Scholz, G., Lalljie, S., Somoza, V., Knorr, D., Jasti, P. R., \& Eisenbrand, G. (2010). A review on the beneficial aspects of food processing. Molecular Nutrition \& Food Research, 54(9), 1215-1247. https://doi.org/10. 1002/mnfr.200900608.

Bogdanov, S. (1997). Nature and origin of the antibacterial substances in honey. LWT-Food Science and Technology, 30(7), 748-753. https:// doi.org/10.1006/fstl.1997.0259.

Brand-Williams, W., Cuvelier, M. E., \& Berset, C. (1995). Use of a free radical method to evaluate antioxidant activity. LWT-Food Science and Technology, 28, 25-30. https://doi.org/10.1016/S00236438(95)80008-5.

Budziak, I., Arczewska, M., Sachadyn-Król, M., Matwijczuk, A., Waśko, A., Gagoś, M., \& Kamiński, D. M. (2018). Effect of polyols on the 
DMPC lipid monolayers and bilayers. Biochimica et Biophysica Acta - Biomembranes, 1860(11), 2166-2174. https://doi.org/10. 1016/j.bbamem.2018.08.014.

Bundit, T., Anothai, T., Pattaramart, P., Roongpet, T., \& Chuleeporn, S. (2016). Comparison of antioxidant contents of Thai honeys to Manuka honey. Malaysian Journal of Nutrition, 22(3), 413-420.

Ciappini, M. C., \& Stoppani, F. S. (2014). Determination of antioxidant capacity, flavonoids, and total phenolic content in eucalyptus and clover honeys. Journal of Apicultural Science, 58(1), 103-111. https://doi.org/10.2478/jas-2014-0010.

COUNCIL DIRECTIVE 2001/110/EC of 20 December 2001 relating to honey. Official Journal of the European Communities.

Dong, R., Zheng, Y., \& Xu, B. (2011). Phenolic profiles and antioxidant capacities of Chinese unifloral honeys from different botanical and geographical sources. Food and Bioprocess Technology, 6(3), 762 770. https://doi.org/10.1007/s11947-011-0726-0.

Escriche, I., Visquert, M., Juan-Borrás, M., \& Fito, P. (2009). Influence of simulated industrial thermal treatments on the volatile fractions of different varieties of honey. Food Chemistry, 112(2), 329-338. https://doi.org/10.1016/j.foodchem.2008.05.068.

Fang, Z., \& Bhandari, B. (2011). Effect of spray drying and storage on the stability of bayberry polyphenols. Food Chemistry, 129(3), 11391147. https://doi.org/10.1016/j.foodchem.2011.05.093.

García-Tenesaca, M., Navarrete, E. S., Iturralde, G. A., Villacrés Granda, I. M., Tejera, E., Beltrán-Ayala, P., Giampieri, F., Battino, M., \& Alvarez-Suarez, J. M. (2018). Influence of botanical origin and chemical composition on the protective effect against oxidative damage and the capacity to reduce in vitro bacterial biofilms of monofloral honeys from the Andean region of Ecuador. International Journal of Moleculat Sciences, 19, 45. https://doi. org/10.3390/ijms19010045.

Gharsallaoui, A., Roudaut, G., Chambin, O., Voilley, A., \& Saurel, R. (2007). Applications of spray-drying in microencapsulation of food ingredients: An overview. Food Research International, 40(9), 1107-1121. https://doi.org/10.1016/j.foodres.2007.07.004.

Ioannou, I., \& Ghoul, M. (2012). Biological activities and effects of food processing on flavonoids as phenolic antioxidants. In M. Petre (Ed.), Advances in applied biotechnology (pp. 101-124). Intech.

Jedlińska, A., Samborska, K., Janiszewska-Turak, E., Witrowa-Rajchert, D., Seuvre, A.-M., \& Voilley, A. (2018). Physicochemical properties of vanilla and raspberry aromas microencapsulated in the industrial conditions by spray drying. Journal of Food Process Engineering, (May), 1-11. https://doi.org/10.1111/jfpe.12872.

Jedlińska, A., Samborska, K., Wieczorek, A., Wiktor, A., OstrowskaLigęza, E., Jamróz, W., Skwarczyńska-Maj, K., Kiełczewski, D., Błażowski, Ł., Tułodziecki, M., \& Witrowa-Rajchert, D. (2019). The application of dehumidified air in rapeseed and honeydew honey spray drying - process performance and powders properties considerations. Journal of Food Engineering, 245, 80-87. https://doi. org/10.1016/j.jfoodeng.2018.10.017.

Jerković, I., Kuś, P. M., Tuberoso, C. I. G., \& Šarolić, M. (2014). Phytochemical and physical-chemical analysis of polish willow (Salix spp.) honey: Identification of the marker compounds. Food Chemistry, 145, 8-14. https://doi.org/10.1016/j.foodchem.2013.08.004.

Juan-Borrás, M., Soto, J., Gil-Sánchez, L., Pascual-Maté, A., \& Escriche, I. (2016). Antioxidant activity and physico-chemical parameters for the differentiation of honey using a potentiometric electronic tongue. Journal of the Science of Food and Agriculture, 97(7), 2215-2222. https://doi.org/10.1002/jsfa.8031.

Kamiński, D. M., Matwijczuk, A., Pociecha, D., Górecka, E., Niewiadomy, A., Dmowska, M., \& Gagoś, M. (2012). Effect of 2-(4fluorophenylamino)-5-(2,4-dihydroxyphenyl)-1,3,4-thiadiazole on the molecular organisation and structural properties of the DPPC lipid multibilayers. Biochimica et Biophysica Acta - Biomembranes, 1818(11), 2850-2859. https://doi.org/10.1016/j.bbamem.2012.07.013.
Kasprzyk, I., Depciuch, J., Grabek-Lejko, D., \& Parlinska-Wojtan, M. (2018). FTIR-ATR spectroscopy of pollen and honey as a tool for unifloral honey authentication. The case study of rape honey. Food Control, 84, 33-40. https://doi.org/10.1016/j.foodcont.2017.07.015.

Kha, C. T., Nguyen, H. M., \& Roach, D. P. (2010). Effects of spray drying conditions on the physicochemical and antioxidant properties of the Gac (Momordica cochinchinensis) fruit aril powder. Journal of Food Engineering, 98, 385-392. https://doi.org/10.1016/j. jfoodeng.2010.01.016.

Khalil, M. I., Sulaiman, S. A., \& Boukraa, L. (2010). Antioxidant properties of honey and its role in preventing health disorder. The Open Nutraceuticals Journal, 3(1), 6-16. https://doi.org/10.2174/ 18763960010030100006.

Kluczyk, D., Matwijczuk, A., Górecki, A., Karpińska, M. M., Szymanek, M., Niewiadomy, A., \& Gagoś, M. (2016). Molecular organization of dipalmitoylphosphatidylcholine bilayers containing bioactive compounds 4-(5-heptyl-1, 3, 4-thiadiazol-2-yl) benzene-1, 3-diol and 4-(5-methyl-1, 3, 4-thiadiazol-2-yl) benzene-1, 3-diols. The Journal of Physical Chemistry B, 120(47), 12047-12063. https:// doi.org/10.1021/acs.jpcb.6b09371.

Kücük, M., Kolayh, S., \& Karaoglu, S. (2007). Biological activities and chemical composition of three honeys of different types from Anatolia. Food Chemistry, 100, 526-534. https://doi.org/10.1016/j. foodchem.2005.10.010.

Kuś, P. M., \& van Ruth, S. (2015). Discrimination of polish unifloral honeys using overall PTR-MS and HPLC fingerprints combined with chemometrics. LWT-Food Science and Technology, 62, 6975. https://doi.org/10.1016/j.lwt.2014.12.060.

Kuś, P. M., Jerković, I., Tuberoso, C. I. G., Marijanović, Z., \& Congiu, F. (2014a). Cornflower (Centaurea cyanus L.) honey quality parameters: chromatographic fingerprints, chemical biomarkers, antioxidant capacity and others. Food Chemistry, 142, 12-18. https://doi. org/10.1016/j.foodchem.2013.07.050.

Kuś, P. M., Congiu, F., Teper, D., Sroka, Z., Jerković, I., \& Tuberoso, C. I. G. (2014b). Antioxidant activity, color characteristics, total phenol content and general HPLC fingerprints of six polish unifloral honey types. LWT - Food Science and Technology, 55(1), 124-130. https:// doi.org/10.1016/j.lwt.2013.09.016.

Lachman, J., Orsák, M., Hejtmánková, A., \& Kovárová, E. (2010). Evaluation of antioxidant activity and total phenolics of selected Czech honeys. Food Science and Technology, 43, 52-58. https:// doi.org/10.1016/j.lwt.2009.06.008.

Mahdavi, S. A., Jafari, S. M., Ghorbani, M., \& Assadpoor, E. (2014). Spray-drying microencapsulation of anthocyanins by natural biopolymers: A review. Drying Technology, 32, 509-518. https://doi. org/10.1080/07373937.2013.839562.

Manyi-Loh, C. E., Ndip, R. N., \& Clarke, A. M. (2011). Volatile compounds in honey: A review on their involvement in aroma, botanical origin determination and potential biomedical activities. International Journal of Molecular Sciences, 12(12), 9514-9532. https://doi.org/10.3390/ijms12129514.

Meda, A., Lamien, C. E., Romito, M., Millogo, J., \& Nacoulma, O. G. (2005). Determination of the total phenolic, flavonoid and proline contents in Burkina Fasan honey, as well as their radical scavenging activity. Food Chemistry, 91(3), 571-577. https://doi.org/10.1016/j. foodchem.2004.10.006

Murugesan, R., \& Orsat, V. (2012). Spray drying for the production of nutraceutical ingredients - a review. Food and Bioprocess Technology, 5(1), 3-14. https://doi.org/10.1007/s11947-011-0638-z.

Nicoli, M. C., Anese, M., \& Parpinel, M. (1999). Influence of processing on the antioxidant properties of fruit and vegetable. Trends in Food Science and Technology, 10, 94-100. https://doi.org/10.1016/ S0924-2244(99)00023-0.

Nurhadi, B., Andoyo, R., Mahani, \& Indiarto, R. (2012). Study the properties of honey powder produced from spray drying and vacuum drying method. International Food Research Journal, 19(3), 907-912. 
Penbunditkul, P., Yoshii, H., Ruktanonchai, U., Charinpanitkul, T., Assabumrungrat, S., \& Soottitantawat, A. (2012). The loss of OSA modified starch emulsifier property during the high-pressure homogeniser and encapsulation of multi-flavour bergamot oil. Food Science and Technology, 47, 2325-2333. https://doi.org/10.1111/j. 1365-2621.2012.03106.x.

Pérez-Pérez, E., Vit, P., \& Huq, F. (2013). Flavonoids and polyphenols in studies of honey antioxidant activity. International Journal of Medicinal Plant and Alternative Medicine, 1(4), 63-72.

Petretto, G. L., Tuberoso, C. I. G., Vlachopoulou, G., Atzei, A., Mannu, A., Zrirad, S., \& Pintore, G. (2016). Volatiles, color characteristics and other physico-chemical parameters of commercial Moroccan honeys. Natural Product Research, 30, 286-292. https://doi.org/ 10.1080/14786419.2015.1056186.

Pisoschi, A. M., \& Negulescu, G. P. (2012). Methods for total antioxidant activity setermination: A review. Biochemistry and Analytical Biochemistry, 01(01), 1-10. https://doi.org/10.4172/2161-1009. 1000106.

Radovic, B. S., Careri, M., Mangia, A., Musci, M., Gerboles, M., \& Anklam, E. (2001). Contribution of dynamic headspace GC \pm MS analysis of aroma compounds to authenticity testing of honey. Food Chemistry, 72, 511-520. https://doi.org/10.1016/S0308-8146(00) 00263-6.

Samborska, K., \& Czelejewska, M. (2014). The influence of thermal treatment and spray drying on the physicochemical properties of polish honeys. Journal of Food Processing and Preservation, 38(1), 413-419. https://doi.org/10.1111/j.1745-4549.2012.00789.x.

Samborska, K., Gajek, P., \& Kamińska-Dwórznicka, A. (2015). Spray drying of honey: The effect of drying agents on powder properties. Polish Journal of Food and Nutrition Sciences, 65(2), 109-118. https://doi.org/10.2478/pjfns-2013-0012.

Samborska, K., Wasilewska, A., Gondek, E., Jakubczyk, E., \& Kamińska-Dwórznicka, A. (2017). Diastase activity retention and physical properties of honey/arabic gum mixtures after spray drying and storage. International Journal of Food Engineering, 13(6). https://doi.org/10.1515/ijfe-2016-0320.

Shahidi, F., \& Han, X. Q. (1993). Encapsulation of food ingredients. Critical Reviews in Food Science and Nutrition, 33, 501-547. https://doi.org/10.1080/10408399309527645.

Sharma, K., Ko, E. Y., Assefa, A. D., Ha, S., Nile, S. H., Lee, E. T., \& Park, S. W. (2015). Temperature-dependent studies on the total phenolics, flavonoids, antioxidant activities, and sugar content in six onion varieties. Journal of Food and Drug Analysis, 23(2), 243252. https://doi.org/10.1016/j.jfda.2014.10.005.

Shi, Q., Fang, Z., \& Bhandari, B. (2013). Effect of addition of whey protein isolate on spray-drying behavior of honey with maltodextrin as a carrier material. Drying Technology, 31, 1681-1692. https://doi. org/10.1080/07373937.2013.783593.

Singleton, V. L., \& Rossi, J. A. (1965). Colorimetry of total phenolics with phosphomolybolic-phosphotungstic acid reagents. American Journal of Enolology and Viticulture, 16, 144-158.

Suhag, Y., \& Nanda, V. (2015). Optimisation of process parameters to develop nutritionally rich spray-dried honey powder with vitamin C content and antioxidant properties. International Journal of Food Science and Technology, 50(8), 1771-1777. https://doi.org/10.1111/ ijfs. 12841.

Suhag, Y., \& Nanda, V. (2016a). Optimization for spray drying process parameters of nutritionally rich honey powder using response surface methodology. Cogent Food and Agriculture, 2(1), 1-12. https:// doi.org/10.1080/23311932.2016.1176631.

Suhag, Y., \& Nanda, V. (2016b). Evaluation of different carrier agents with respect to physico-chemical, functional and morphological characteristics of spray dried nutritionally rich honey powder. Journal of Food Processing and Preservation, 40(6), 1429-1437.

Suhag, Y., Nayik, G. A., \& Nanda, V. (2016). Effect of gum arabic concentration and inlet temperature during spray drying on physical and antioxidant properties of honey powder. Journal of Food Measurement and Characterization, 10(2), 350-356.

Sun-Waterhouse, D., Wadhwa, S. S., \& Waterhouse, G. I. N. (2013). Spray-drying microencapsulation of polyphenol bioactives: A comparative study using different natural fibre polymers as encapsulants. Food and Bioprocess Technology, 6, 2376-2388. https://doi.org/10. 1007/s11947-012-0946-y.

Svečnjak, L., Bubalo, D., Baranović, G., \& Novosel, H. (2015). Optimization of FTIR-ATR spectroscopy for botanical authentication of unifloral honey types and melissopalynological data prediction. European Food Research and Technology, 240(6), 1101-1115. https://doi.org/10.1007/s00217-015-2414-1.

Tapia-Campos, E., Castañeda-Saucedo, M. C., Ramírez-Anaya, J. P., Macías-Macías, J. O., Barajas-Pérez, J. S., Tapia-González, J. M., \& Alaniz-Gutierrez, L. (2017). Physical-chemical characterization, phenolic content and consumer preferences of Apis mellifera honey in southern Jalisco. Interciencia, 42(9), 603-609.

Tiwari, U., \& Cummins, E. (2013). Factors influencing levels of phytochemicals in selected fruit and vegetables during pre- and postharvest foor processing operations. Food Research International, 50(2), 497-506. https://doi.org/10.1016/j.foodres.2011.09.007.

Tonon, R. V., Brabet, C., Pallet, D., Brat, P., \& Hubinger, M. D. (2009). Physicochemical and morphological characterisation of açai (Euterpe oleraceae Mart.) powder produced with different carrier agents. International Journal of Food Science and Technology, 44(10), 1950-1958. https://doi.org/10.1111/j.1365-2621.2009.02012.x.

Tonon, R. V., Brabet, C., \& Hubinger, M. D. (2010). Anthocyanin stability and antioxidant activity of spray-dried açai (Euterpe oleracea Mart.) juice produced with different carrier agents. Food Research International, 43(3), 907-914. https://doi.org/10.1016/j.foodres. 2009.12.013.

Turkmen, N., Sari, F., \& Velioglu, Y. S. (2005). The effect of cooking methods on total phenolics and antioxidant activity of selected green vegetables. Food Chemistry, 93(4), 713-718. https://doi.org/10. 1016/j.foodchem.2004.12.038.

Vallianou, N. (2014). Honey and its anti-inflammatory, anti-bacterial and anti-oxidant properties. General Medicine: Open Access, 02(02). https://doi.org/10.4172/2327-5146.1000132.

Vallianou, N. G., Gounari, P., Skourtis, A., Panagos, J., \& Kazazis, C. (2014). Honey and its anti-inflammatory, anti-bacterial and antioxidant properties. Gen Med (Los Angel), $2,2$.

Veríssimo, M. I. S., Gamelas, J. A. C., Evtuguin, D. V., Teresa, M., \& Gomes, S. R. (2017). Determination of 5-hydroxymethylfurfural in honey, using headspacesolid-phase microextraction coupled with a polyoxometalate-coated piezoelectric quartz crystal. Food Chemistry, 220, 420-426. https://doi.org/10.1016/j.foodchem. 2016.09.204.

Verzera, A., Campisi, S., Zappala, M., \& Bonnaccorsi, I. (2001). SPMEGC-MS analysis of honey volatile components for the characterization of different floral origin. American Laboratory, 7, 18-21.

Waterhouse, G. I. N., Waterhouse, D. S., Su, G., Zhao, H., \& Zhao, M. (2017). Spray-drying of antioxidant-rich blueberry waste extracts; interplay between waste pretreatments and spray-drying process. Food and Bioprocess Technology, 10, 1074-1092. https://doi.org/ 10.1007/s11947-017-1880-9.

Wolski, T., Tambor, K., Rybak-Chmielewska, H., \& Kedzia, B. (2006). Identification of honey volatile components by solid phase microextraction (SPME) and gas chromatography/mass spectrometry (GC/MS). Journal of Apicultural Science, 50(2), 115.

Wootton, M., Edwards, R. A., \& Faraji-Haremi, R. (1978). Effect of accelerated storage conditions on the chemical composition and properties of Australian honeys. Journal of Apicultural Research, 17(3), 167-172.

Publisher's Note Springer Nature remains neutral with regard to juris dictional claims in published maps and institutional affiliations. 